\title{
Research on Short-term Investment Accounting
}

\author{
Liqin $\mathrm{Fu}$ \\ Modern Economics \& Management College of JXUFE
}

\section{Keywords: Short-term investments; Accounting; Financial}

\begin{abstract}
With the economic development, China's investment industry is becoming more and more prosperous. Now people have a more reasonable way to use funds and the people who have idle funds begin amateur investment banking. Most financial products are short-term investments. In order to increase fund income, some enterprises buy bonds or shares by the cash which exceeds the daily operational needs to obtain a higher interest, dividend income and share value. Its characteristics are liquidity and small risk. The short-term investment is next only to monetary fund can be sold at any time in the share market. The short-term investment changes generally small in short term, so both the income and the risk are small. So the basic concept of short-term financial investment shall be understand. This paper briefly introduces the characteristics and the accounting principles of the short-term investment. Finally, the paper introduces the finance and investment accounting methods, and hopes to be helpful to the short term investment users.
\end{abstract}

\section{Introduction}

With the development of economy, more and more people choose financial investment. At present, inflation is inevitable, how to make their money not devalue is another reason for a lot of people choose the investment. Now the financial products emerge in endless stream, in which the most popular are shares and bond funds. Noe the investment channels have become simple. Financial products can be bought in banks, insurance companies and securities companies. Many people just know the names of financial products, but do not know about the accounting modes and the so-called investment. Many companies purchase the corresponding financial productions by free flow of funds to increase the corresponding income of the companies. Especially in share futures market, short term capital flow is considerable. Especially in recent years China's share market has a good tread, Chinese share market liquidity is also increasing. But there are few people who understand the accounting method and revenue ratios of short-term investment, so this paper discusses the current short-term investment, studies the characteristics of short-term investments and illustrates two accounting methods of short-term investment by examples, with the hope to help the people who focus on short-term investment.

\section{Characteristics of Short Term Investment}

Short term investment is liquid assets, it has the following characteristics:

1. The investment must be available at any time on the market.

2. The management of an enterprise intends to turn it into cash within a fiscal year.

3. Very easy to liquidate.

4. Holding time is short. The short-term investments are generally not for long-term holders, so the holding time is not prepared for more than a year.

5. It is not the investment which is to control, jointly control the unit which is invested or have major impact on the unit which is invested.

Especially, for long-term debt investment with clear expiration date, even if the remaining term has been shorter than a year, it shall not be turned into short-term investment. Because the purpose of the investment is not changed from the enterprise hold the investment for a long-term until the expiration date. But this part of the asset has become current assets, so in the preparation of the balance sheet, it shall be shown separately in "long-term debt investment due within one year". 


\section{The Accounting Principles of Short-Term Investment}

Short-term investment shall be accounted in accordance with the following principles:

1. When obtaining, the short-term investment shall be measured in accordance with the cost of investment. When obtaining, the investment costs of the short-term investment shall be determined according to the follows:

(1) The short-term investments which are purchased in cash shall be accounted according to the full price of the actual payment, including taxes, fees and other related costs.

(2) The short-term investments which are invested by investors shall be accounted by the value which is confirmed by each party which shall be taken as the costs of short-term investments.

(3) The short-term investments which are obtained in non monetary transaction shall be accounted according to the book value of the assents in transaction and the related payable taxes and fees which shall be taken as the costs of short-term investments.

2. The cash dividends or interests on a short-term investment shall offset the book value of the investment at the time of the actual receipt, except for the cash dividends which have been accounted into "receivable dividend" or "receivable interests".

3. An enterprise shall, at the end of the term, measure the cost and market value of the short-term investment. The difference between the market price and the cost shall be the provision of short-term investment allowance. The provision for short - term investment provision shall be accounted for separately. In the balance sheet, the short-term investment projects shall be reflected in accordance with the net amount after deducting the provision.

4. In the treatment of short-term investments, the difference between the book value and the actual purchase price of the short-term investment shall be taken as the investment profit and loss of the current period. The enterprise entrusted loans shall be regarded as short-term investment accounting. However, entrusted loans shall be included in the interest and included in the profit and loss; the enterprise shall stop counting the interest if the interest payments cannot be recovered on schedule and shall be taken as the original interests. At the end of the term, the entrusted loans of enterprises shall be accounted the corresponding impairment provision in accordance with the requirements of the impairment of assets.

\section{The Business Accounting Method of Short Term Investment}

Short-term investment business accounting contents include short-term bond investments and short-term share investments.

1. Short-term bond investment accounting

Short-term bond investment accounting includes the purchase, transfer (or sale) and maturity payment of short-term bonds.

Whether the purchase of short-term bonds on the date of issue (or the date of payment) or in the interest period is the basis to divide the short-term bonds into interest bearing purchase and non interest bearing purchase. No matter interest bearing purchase or non interest bearing purchase, the actual cost of the purchase is the actual payment of the price, which has been introduced before, not repeating.

Example 1: A commodity circulation enterprise purchased a one-year bond issued on the same day by the idle funds on $1^{\text {st }}$, January, 2003. The value is 50000 yuan, the annual interest rate is $12 \%$ and payment fees and brokerage commission are 1000 yuan, which shall be accounted as follows:

Borrow: Short-term investment - bond investment 51000
Loan: Bank deposit
51000

As a short-term bond investment, if enterprises are in urgent need of funds for the production and business operation, the short-term bonds can be readily transferred or sold. When transferring or selling, the enterprises may get benefit due to the rice of the market price or it may get loss due to the decline of the market price. The difference between the income of transferring or selling the bonds and the actual costs of purchasing the bonds shall be recognized as investment gains or losses. 
Example 2. A commodity circulation enterprise sold the one-year bonds which were purchased with the value of 50000 yuan on $1^{\text {st }}$, August, 2003. The book interest rate is $8 \%$. The enterprise interest is 2333.3 yuan and the price is $\mathbf{5 2 3 3 3 . 3}$ yuan, which shall be accounted as follows:

Borrow: Bank deposit 52333.3

Loan: Short-term investment - bond investment 50000

Investment income 2333.3

2. Short term share accounting

Short-term share investment accounting includes the acquisition, dividend income, transfer (or sale) of shares and so on.

The actual costs of acquisition cost of short-term share investment shall be accounted according to the actual payment when purchasing the shares, including the purchase price, brokerage commissions, fees and other related expenses. If the actual payment of the price contains the dividends which are declared but not issued, the dividends shall be taken as account receivable which shall not be included in the costs of investment.

Example 3: Enterprise A purchased 500 shares of Company 1 on $1^{\text {st }}$, May, 2002 with the book price of 110 yuan of each share. At the same time, the enterprise paid 500 yuan, including brokerage commission, fees, etc., which shall be accounted as follows:

Borrow: Short-term investment - share investment 55500

Loan: Bank deposit 55500

Example 4: A commodity circulation enterprise purchased 300 shares of Company B on $1^{\text {st }}$, January, 2002 and paid 3500 yuan, including dividends 500 yuan which was declared to issue but not paid, which shall be accounted as follows:

Borrow: Short-term investment - share investment 3000

Dividends receivable 500

Loan: Bank deposit 3500

As the short-term share investments, dividends usually shall not be accounted. Only until the enterprise offering shares (the enterprise which is invested) declares dividends and the actual payment of dividends, will the investment enterprises treat the dividend income as reducing the investment costs.

\section{Conclusion}

With the improvement of people's living standard, investment banking has been slowly into people's line of sight. Insurance does not only to deceive. People began to have a new understanding of insurance and began to believe in financial products and short-term investments. Short-term investment is not only the trend in the future, but also the one that people have to adapt slowly. Economy has been concerned since the modernization, investment is also a part of the economic development. This paper describes the characteristics of short-term investment and explores the short-term investment accounting by example, in order to make more people understand the investment accounting.

\section{References}

[1] Easton P, Taylor G, Shroff P, et al. Using Forecasts of Earnings to Simultaneously Estimate Growth and the Rate of Return on Equity Investment [J]. Journal of Accounting Research, 2002, 40(40):657-676.

[2] Alao S, Lee B. After the doc.com bubble has burst: UK Venture Capitalists, short-term accounting criteria and investment in start-up companies [J]. Management, 2003, 7.

[3] Hunjra A I, Akhtar M N, Rehman K U. Determinants of Short-Term Investment Decision-Making [J]. Actual Problems of Economics, 2012, 11(11):356-363.

[4] Powers O S. Fair values: A change in investment accounting [J]. National Public Accountant, 1995. 
[5] Langberg N, Sivaramakrishnan K. Voluntary Disclosures and Analyst Feedback [J]. Journal of Accounting Research, 2010, 48(3):603-646.

[6] Mavruk T, Carlsson E. How long is a long-term-firm investment in the presence of governance mechanisms? [J]. Social Science Electronic Publishing, 2015, 5(1):1-33.

[7] Tsujimura K, Motoyoshi K, Morishima Y. Generational Accounting around the World [J]. Ssrn Electronic Journal, 2000, 89(2):161-166.

[8] Olstein R A. Reality Check: Accounting Alerts for Investment Advisors [J]. Cpa Journal, 2006(Jan).

[9] Maureen McNichols, Brett Trueman. Public disclosure, private information collection, and short-term trading $\hat{\sim}[\mathrm{J}]$. Journal of Accounting \& Economics, 1994, 17(1-2):69-94.

[10]Milian J A. Insider sales based on short-term earnings information [J]. Review of Quantitative Finance \& Accounting, 2015, 47:1-20.

[11] Waegelein J F. The association between the adoption of short-term bonus plans and corporate expenditures [J]. Journal of Accounting \& Public Policy, 1988, 7(1):43-63.

[12] Yong J, Pham A K. The long-term linkages between direct and indirect property in Australia [J]. Journal of Property Investment \& Finance, 2015, 33(4):374-392. 